\title{
PERANCANGAN JARINGAN FEMTOCELL PADA JARINGAN 4G LTE DI GEDUNG REKTORAT UNIVERSITAS RIAU
}

\author{
Ahmad Mudhhirulhaq Syam \\ Fakultas Teknik, Program Studi Teknik Elektro \\ Universitas Riau \\ Email: ahmad.mudhhirulhaq6051@student.unri.ac.id \\ Daniel Junianto \\ Fakultas Teknik, Program Studi Teknik Elektro \\ Universitas Riau \\ Email: daniel.junianto6111@student.unri.ac.id \\ Dyan Anggreani D. \\ Fakultas Teknik, Program Studi Teknik Elektro \\ Universitas Riau \\ Email: dyan.anggreani6088@student.unri.ac.id \\ Ilham Ferdian Suganda \\ Fakultas Teknik, Program Studi Teknik Elektro \\ Universitas Riau \\ Email: ilham.ferdian2554@student.unri.ac.id \\ Yusnita Rahayu \\ Fakultas Teknik, Program Studi Teknik Elektro \\ Universitas Riau \\ Email: yusnita.rahayu@lecturer.unri.ac.id
}

\begin{abstract}
ABSTRAK
Makalah ini membahas perancangan jaringan indoor 4G LTE pada Gedung Rektor Universitas Riau menggunakan software aplikasi desktop Radiowave Propagation Simulator (RPS) 5.4. Perancangan jaringan indoor menggunakan model propagasi COST 231 Multi-Walls. Berdasarkan perhitungan area cakupan menggunakan model propagasi COST 231 Mulit-Wall yang telah dilakukan, dibutuhkan sebanyak 6 Femtocell Access Point (FAP) di setiap lantai. Analisis yang berhasil diperoleh dalam desain skenario posisi FAP pada tengah ruangan secara sejajar pada setiap lantai dengan level daya rata-rata $-64,93 \mathrm{dBm}$ dan SIR 6,72 dBm. Perancangan jaringan Femctocell 4G LTE menggunakan software RPS 5.4 dan model propagasi COST 231 Multi-Walls Mode dapat diterapkan ke Gedung Rektorat Universitas Riau.
\end{abstract}

Kata kunci: femtocell; 3GPP 4G LTE; maximum allowed pathloss; radiowave propagation simulator.

\section{ABSTRACT}

This paper discusses the design of $4 G$ LTE indoor network at the Riau University Rector Building and then simulated in desktop software Radiowave Propagation Simulator (RPS) 5.4. The design of the 4G LTE indoor network uses the COST 231 Multi-Walls propagation model. Based on the calculation of coverage using the COST 231 Mulit-Wall propagation model that has been done, as many as 6 Femtocell Access Points (FAP) are needed on each floor. The successful analysis was obtained in the design of the FAP coating scenarios in the middle of the room parallel to each floor with an average power level of -64.93 $\mathrm{dBm}$ and SIR of $6.72 \mathrm{dBm}$. The 4G LTE Femtocell network design uses RPS 5.4 software and the COST 231 Multi-Wall COST propagation model can be applied to the Rectorate Building of the University of Riau.

Keywords: femtocell; $3 G P P 4 G$ LTE; maximum allowed pathloss; radiowave propagation simulator. 


\section{PENDAHULUAN}

Seiring dengan perkembangan dalam telekomunikasi saat ini menjadikan permintaan layanan pada komunikasi semakin terjadi meningkat. Hal ini ditandai dengan banyaknya permintaan komunikasi sampai pada saat ini. Namun seiring dengan berkembangnya suatu komunikasi suara tidaklah memadai, maka dibutuhkan suatu layanan komunikasi data yang kecil dapat mengatasi suatu layanan data yang cukup besar.

Teknologi komunikasi jaringan tanpa kabel terbagi menjadi komunikasi jaringan outdoor dan komunikasi jaringan indoor. Komunikasi jaringan indoor diciptakan sebagai membantu suatu jaringan pada outdoor yang menjadikan sinyal pada outdoor lebih sangat bagus lagi. Komunikasi pada jaringan suatu indoor merupakan sistem sebagai perangkat pengirim dan penerima diletakan pada dalam suatu bangunan dengan aksud sebagai memberikan layanan telekomunikasi didalam bangunan. Ada perbedaan propagasi antara indoor dan outdoor yaitu pada kualitas sinyal dari ketebalan dinding suatu bangunan, bentuk ruangan juga mempengaruhi pantulan sinyal dalam ruangan. Pada jaringan indoor terdapat Femtocell[1].

Budi Utomo, (2012), yang membahas tentang "Simulasi Link Budget Pada Sel Femto Teknologi Telekomunikasi LTE (Long Term Evolution)". Pada pembahasan tersebut adalah simulasi yang berhubungan pada dampak interferensi pada sejumlah femto sel LTE yang digunakan pada daerah sel makro LTE. Pada penjelasan kualiti pada sinyal SINR (Signal Interference Noise Ratio) pada bagian penerima atau downlink pada sel macro yang dikerjakan berdasarkan pada pengolahan sebuah link budget pada interferensi menggunakan perangkat lunak Lab View 2009. Hasil dari simulasi propagasi terkecil untuk User Equitment (UE) ada diluar gedung yaitu 97,021 dB dan pada kejauhan $50 \mathrm{~m}$ sehingga mengalami penambahan sampai $142,849 \mathrm{~dB}$ untuk jarak $1 \mathrm{~km}$ dan di suatu tempat nilainya adalah 112,021 dB dan pada $50 \mathrm{~m}$ memiliki nilai $157,849 \mathrm{~dB}$ di kejauhan $1 \mathrm{~km}$. Besar daya terima dihasilkan pada sel macro lebih cukup besar dari pada sel femto yang di dalam tempat ataupun padadiluar ruangan pada perbandingan antara jarak pada 1 meter - 50 meter. Bertambahnya banyaknya FAP di suatu ruangan sel macro, yang menjadikan angka SINR yang diterima oleh user dari sel femto dengan sel macro mengecil dikarena adanya interferensi pada sebuah FAP lainnya. Jumlah nilai pada SINR makro downlink maksimal pada nilai 27,4348 dB dan pada SINR macro downlink terkecil[2].

\section{LANDASAN TEORI}

\subsection{COST 231 Multi-Wall Model}

COST 231 Multi-Wall memiliki model perhitungan propagasi dengan mempertimbangkan semua aspek bidang vertikal pada bangunan yang berada diantara transmitter dan receiver, dan juga mempertimbangkan properti material pada bidang bangunan. Jumlah dinding pada bidang vertikal dan properti materialnya yang dilalui oleh sinyal akan mempengaruhi besar attenuasi, sehingga pada COST 231 Multi-Wall menghasilkan model yang sangat mendekati dengan kondisi ruang. Karena alasan inilah, penelitian ini menggunakan model propagasi COST 231 MWM. Dengan persamaan sebagai berikut:

$$
\mathrm{LT}=\mathrm{LFSL}+\mathrm{LC} \sum_{i=1}^{M} n w i, L w i+n^{\left[\frac{n f+2}{n f+1}-b\right]} L f
$$

Keterangan :

LFSL $=$ Loss Free Space Lose

$\mathrm{LC}=$ Constant Loss

$\mathrm{M}=$ Numbers of wall type

nwi $=$ number of wall crossed by the path

Lwi $=$ Wall type loss

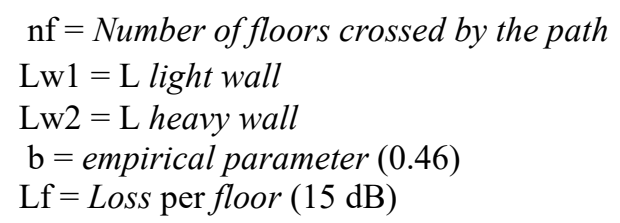

$\mathrm{nf}=$ Number of floors crossed by the path

$\mathrm{b}=$ empirical parameter $(0.46)$

$\mathrm{Lf}=$ Loss per floor $(15 \mathrm{~dB})$

\subsection{RPS (Radio Wave Propagation Simulator)}

RPS adalah software aplikasi desktop yang dibuat oleh organisasi Developtment Software yang berguna sebagai simulasi dan analisa rancangan komunikasi pada indoor dan simulasi pada perancangan FAP (Femtocell Access Point) serta memprediksi area cakupan dari sebuah FAP.

\subsection{G-Net Track Lite}

G-Net Track Lite merupakan sebuah aplikasi pada perangkat Android yang dapat digunakan untuk memonitor jaringan dan walk test. Teknologi seluler yang didukung oleh aplikasi G-Net Track ini yaitu pada jaringan GSM, CDMA, EVDO, HSDPA, UMTS, dan LTE. 


\subsection{Parameter Performansi LTE}

Reference Signal Received Power (RSRP) merupakan parameter performansi pada perancangan ini. RSRP merupakan besar power yang diterima pada sisi user dari sinyal referensi (LTE) pada frekuensi tertentu. Nilai RSRP yang diterima pada sisi user dipengaruhi oleh besar jarak antara user dan site, semakin besar jarak antara user dan site, maka RSRP yang diterima pada sisi user akan semakin kecil. Reference Signal Received Power atau RSRP pada tiap titik-titik di dalam jangkauan cakupan. User yang berada di luar jangkauan cakupan tidak akan memperoleh layanan LTE[3].

Tabel 1. Standar nilai RSRP [4]

\begin{tabular}{cc}
\hline Kategori & Range Nilai RSRP \\
\hline Excellent/Near Cell & $<-90$ \\
Good/Mid Cell & -90 to -105 \\
Fair/Cell Edge & -106 to -110 \\
Poor & -110 to -120 \\
\hline
\end{tabular}

\subsection{Radio Link Budget}

Radio link budget merupakan perhitungan jangkauan cakupan sebuah sel berdasarkan pada nilai MAPL (Maximum Allowable Path-Loss) untuk memperoleh nilai SNR (Signal-to-Noise Ratio) yang serendah mungkin. MAPL adalah nilai redaman (path-loss) maksimal yang diperbolehkan antara pengirim dan penerima. Proses link budget baik untuk sisi downlink maupun sisi uplink digunakan untuk memperoleh nilai MAPL[5]. Nilai Maximum Allowable Path-Loss (MAPL) pada sisi downlink maupun uplink dapat dihitung dengan persamaan berikut[6]:

$$
M A P L=E I R P-S_{N}-I M+G_{R x}-F M
$$

Keterangan:

$$
\begin{array}{ll}
\mathrm{EIRP}=\text { Equipment Isotropic Radiated Power }(\mathrm{dBm}) & \mathrm{S}_{\mathrm{N}}=\text { Receiver Noise Floor }(\mathrm{dBm}) \\
\mathrm{IM}=\text { Interference Margin }(\mathrm{dB}) & \mathrm{G}_{\mathrm{Rx}}=\text { Receiver Antenna Gain }(\mathrm{dBi}) \\
\mathrm{FM}=\text { Fast Fade Margin }(\mathrm{dB}) &
\end{array}
$$

Nilai EIRP dapat dihitung dengan persamaan[6]:

$$
E I R P=P_{T x}+G_{T x}-L_{T x}
$$

Keterangan:

$\mathrm{P}_{\mathrm{Tx}}=$ Transmitter Power $(\mathrm{dBm})$

$$
\mathrm{L}_{\mathrm{Tx}}=\text { Loss }
$$

$\mathrm{G}_{\mathrm{Tx}}=$ Transmitter Antenna Gain $(\mathrm{dBi})$

Nilai Receiver Noise Figure dapat dihitung dengan persamaan[6]:

$$
S_{N}=\text { Noise Figure }(\text { dB })+\text { Thermal Noise }(\mathrm{dBm})
$$

Keterangan:

Thermal Noise $=\mathrm{k}($ Boltzmann $) \times \mathrm{T}(290 \mathrm{~K}) \times \mathrm{B}(\mathrm{Hz})$

\subsection{Perhitungan Jumlah User (Pengguna)}

Pada tahap awal perancangan suatu jaringan dilakukan perhitungan estimasi jumlah user aktif yang akan mengunakan layanan yang akan dirancang. Jumlah pengguna yang aktif dapat dihitung dengan persamaan[7].

$$
P=J u m l a h \text { Ruangan } \times \text { Kapasitas Maksimal Ruangan }
$$

Keterangan :

$\mathrm{P}=$ Jumlah total pengguna ruangan

Pengestimasian jumlah pengguna yang aktif dapat diperoleh dengan menggunakan persamaan berikut[7]: 


$$
\boldsymbol{N}=\boldsymbol{x} \% \boldsymbol{x P}
$$

Keterangan :

$\mathrm{N}=$ Jumlah pegguna aktif

$\mathrm{P}=$ Jumlah total pengguna ruangan

$$
\mathrm{x} \%=\text { Telenditas seluler }(\%)
$$

\subsection{Perhitungan Area Cakupan}

Untuk jumlah FAP (Femtocell Access Point) yang didasarkan pada area cakupan yang terlebih dahulu menghitungkan radius sel yang menggunakan persaman[7]:

$$
L p=F S L=32.45+20 \log f+20 \log d
$$

Keterangan:

$\mathrm{F}=$ Frekuensi Operasi $(\mathrm{MHz}) \quad \mathrm{d}=$ Jarak antar pengirim dan penerima $(\mathrm{km})$

Kemudian menghitung radius dengan menggunakan persaman(1), Perhitungan luas sel dapat dilakukan dengan menggunakan persamaan berikut[7]:

$L=K x d^{2}$

Keterangan :

$\mathrm{L}=$ Luas Sel

$\mathrm{d}=$ Jarak

$\mathrm{K}=$ Konstanta antena (Antenna Omnidirectional $=2,6$ )

Perhitungan jumlah sel dapat menggunakan persaman[7]:

$$
\text { Jumlah Sel }=\text { Luas Area } / \text { Luas Sel }
$$

\section{METODOLOGI PENELITIAN}

\subsection{Tahapan Perencanaan}

Perancangan jaringan indoor akan diterapkan pada Gedung Rektorat Universitas Riau. Gedung Rektorat terbagi menjadi 4 lantai, dan tiap lantai terbagi atas beberapa ruangan. Lantai 1, 2, dan 3 terdiri dari 11 ruangan, dan lantai 4 terdiri dari 7 ruangan. Jumlah ruangan Gedung Rektorat adalah 40 ruangan dimana tiap ruangan dibatasi dengan dinding beton. Denah Gedung Rektorat tiap lantai ditunjukkan pada gambar 1(a) s/d (d). Spesifikasi Gedung Rektorat dapat dilihat dalam tabel 2

Tabel 2. Spesifikasi Tiap Lantai Gedung Rektorat Fakultas Teknik Universitas Riau

\begin{tabular}{ccccc}
\hline Lantai & Tinggi Gedung & Luas Lantai & Jumlah Ruangan & $\begin{array}{c}\text { Jumlah User yang } \\
\text { Aktif }\end{array}$ \\
\hline 1 & 4 & 1496 & 11 & 13 \\
2 & 4 & 1496 & 11 & 13 \\
3 & 4 & 1496 & 11 & 13 \\
4 & 4 & 1496 & 7 & 135 \\
\hline
\end{tabular}

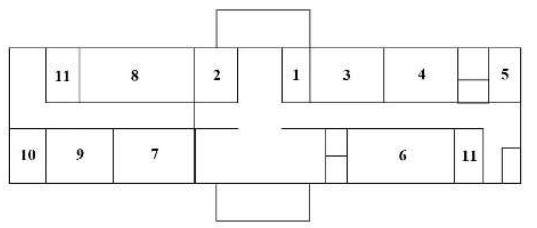

(a)

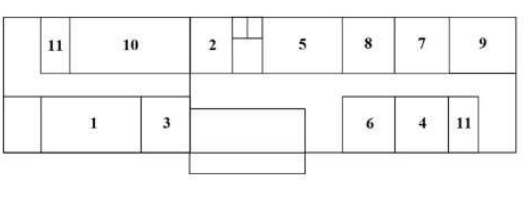

(b) 


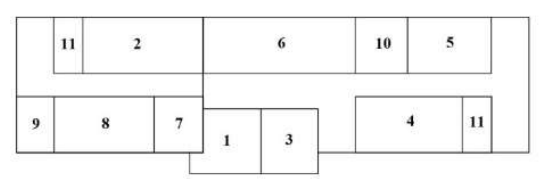

(c)

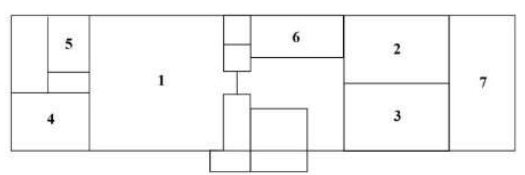

(d)

Gambar 1. Denah Gedung Rektorat Universitas Riau (a) Lantai 1 (b) Lantai 2 (c) Lantai 3 (d) Lantai 4

\subsection{Parameter yang Digunakan}

Beberapa parameter pada perancangan jaringan femtocell yang diperlukan pada pengirim dan penerima dapat dilihat pada Tabel 2 berikut:

Tabel 2. Parameter Transmitter dan Receiver

\begin{tabular}{ccc}
\hline No & Parameter & Transmitter \\
\hline 1 & Jenis antenna & Isotropic Source \\
2 & Posisi pengirim & $\mathrm{x}, \mathrm{y}, \mathrm{z}$ sesuai perancangan \\
3 & Power pengirim $(\mathrm{dBm})$ & 23 \\
4 & Tinggi antena $(\mathrm{m})$ & 4 \\
5 & Cable Loss & 0 \\
7 & Noise figure & 9.2 \\
6 & Carrier frequency $(\mathrm{GHz})$ & 1.8 \\
\hline No & Parameter & Receiver \\
\hline 1 & Daya pancar $(\mathrm{dBm})$ & 20 \\
2 & Tinggi antena dari ground $(\mathrm{m})$ & 4 (per lantai) \\
\hline
\end{tabular}

\subsection{Redaman Indoor}

Perhitungan redaman indoor dilakukan untuk mengetahui besar loss wall material dari bangunan tersebut. Loss wall berupa besar daya redam terhadap sinyal yang disebabkan oleh material bahan dari bangunan seperti lantai, dinding, pembatas antar ruangan, jendela, dan pintu. Setiap material bangunan memiliki nilai redaman yang berbeda dari pada material yang lain. Indor loss bangunan berdasarkan material pada Gedung Rektorat sesuai dengan standar 3GPP ditunjukkan pada Tabel 3 Nilai indoor loss pada tiap lantainya adalah sama.

Tabel 3. Indoor Loss Gedung Rektorat (per Lantai)

\begin{tabular}{cccc}
\hline Jenis hambatan & $\boldsymbol{d B}$ & Jumlah & Total dB \\
\hline Kaca (glass) & 2.8 & 18 & 50.4 \\
Pintu Kayu (wood door) & 4 & 16 & 64 \\
Beton (Concrete) & 3.4 & 4 & 13.6 \\
Total Loss & & & 128 \\
\hline
\end{tabular}

\subsection{Perhitungan Link Budget}

Perhitungan link budget diperlukan dalam perancangan jaringan indoor sebagai parameter untuk mengetahui nilai loss pada Uplink dan Downlink. Tabel 4 berikut menunjukkan beberapa parameter yang diperlukan dalam perhitungan link budget.

Tabel 4. MAPL Uplink dan Downlink

\begin{tabular}{lcc}
\hline \multicolumn{1}{c}{ Transmitter (Mobile Station) } & Uplink & Downlink \\
\hline Daya pancar $(\mathrm{dBm})$ & $23 \mathrm{dBm}$ & $20 \mathrm{dBm}$ \\
Gain antena $(\mathrm{dBi})$ & $0 \mathrm{dBi}$ & $17 \mathrm{dBi}$ \\
Rugi-rugi $(\mathrm{dB})$ & 3 & 0 \\
EIRP & 20 & 37 \\
\hline \multicolumn{1}{c}{ Receiver (Base Station) } & Uplink & Downlink \\
\hline Receiver Noise Figure $(\mathrm{dB})$ & $9,2 \mathrm{~dB}$ & $9,2 \mathrm{~dB}$ \\
Receiver Noise Density/floor $(\mathrm{dBm} / \mathrm{Hz})$ & $-164,8 \mathrm{dBm} / \mathrm{Hz}$ & $-164,8 \mathrm{dBm} / \mathrm{Hz}$ \\
\hline
\end{tabular}




\begin{tabular}{lcc}
\hline Thermal Noise Density $(\mathrm{dBm} / \mathrm{Hz})$ & -174 & -174 \\
SINR $(\mathrm{dB})$ & $32,016 \mathrm{~dB}$ & $32,016 \mathrm{~dB}$ \\
Receiver sensitivity $(\mathrm{dBm})$ & $-132,784$ & $-132,784 \mathrm{dBm}$ \\
Interference margin & 0,89 & 2.72 \\
Fast Fading margin $(\mathrm{dB})$ & $0 \mathrm{~dB}$ & $0 \mathrm{~dB}$ \\
Rx Antena Gain & 17 & 0 \\
MAPL $(\mathrm{dB})$ & $200,91 \mathrm{~dB}$ & $199,08 \mathrm{~dB}$ \\
\hline
\end{tabular}

Dari perhitungan yang dilakukan diperoleh nilai MAPL dari arah downlink sebesar 200,91 dB, dan dari arah uplink sebesar 199,09 dB. Maka selisih antara nilai MAPL uplink dan downlink adalah sebesar $1.83 \mathrm{~dB}$. Karena hasil selisih ini adalah $1.83 \mathrm{~dB}>5 \mathrm{~dB}$ (lebih kecil dari pada $5 \mathrm{~dB}$ ), maka perencanaan ini dapat diterapkan.

\subsection{Perhitungan Area Cakupan}

Perhitungan area cakupan bertujuan untuk menghitung jumlah FAP (Femtocell Access Point) yang diperlukan untuk mencover suatu bangunan. Dengan menggunakan model propagasi COST 231 Multiwall dilakukan perancangan jaringan indoor dan didapat luas area sel antenna indoor sebesar 10,562 $\mathrm{m}$ dan didapat luas cell sebesar $290 \mathrm{~m}^{2}$. Berdasarkan perhitungan area cakupan jumlah FAP yang dibutuhkan dalam perencangan ini adalah 6 FAP yang akan diletakkan pada setiap lantai.

\section{HASIL DAN PEMBAHASAN}

Simulasi perancangan femtocell menggunakan software RPS (Radiowave Propagation Simulator). $\mathrm{Bab}$ ini membahas hasil dari simulasi dengan menggunakan 1 skenario, yaitu skenario peletakan FAP dibagian tengah lorong bagunan Rektorat Universitas Riau. Berdasarkan perhitungan area cakupan jumlah FAP yang digunakan adalah sebanyak 6 FAP pada setiap lantai di Gedung Rektorat Universitas Riau.

\subsection{Hasil Pengukuran Jaringan Provider 3 (Tri)}

Sebelum melakukan perancangan femtocell, terlebih dahulu dilakukan pengukuran kualitas jaringan di lapangan atau pada gedung yang diteliti. Ini bertujuan untuk mengetahui kualitas jaringan awal pada bangunan yang akan dilakukan perancangan femtocell. Berdasarkan standar KPI, level sinyal yang bagus yaitu sebesar $\geq-90 \mathrm{dBm}$.

Untuk melakukan pengukuran jaringan provider 3 (Tri) di Gedung Rektorat Universitas Riau, penelitian ini menggunakan software G-NetTrack Lite v2.4. Pengukuran dilakukan pada setiap lantai rektorat. Hasil pengukuran jaringan pada tiap lantai dapat dilihat pada tabel berikut :

Tabel 5. Hasil pengukuran pada lantai 1

\begin{tabular}{cccc}
\hline Waktu & Cell ID & Level Sinyal (dBm) & Waktu Layanan (s) \\
\hline $12: 17: 57$ & $230021-6$ & -110 & 4 \\
$12: 19: 23$ & $230021-6$ & -102 & 6 \\
$12: 21: 05$ & $230021-6$ & -106 & 2 \\
$12: 22: 13$ & $230021-6$ & -105 & 2 \\
$12: 24: 02$ & $230021-6$ & -109 & 10 \\
$12: 24: 58$ & $230021-6$ & -112 & 4 \\
$12: 25: 14$ & $230021-6$ & -110 & 8 \\
12:25:49 & $230021-6$ & -109 & -106 \\
Rata-rata Level Sinyal (dBm) & & -106 \\
\hline
\end{tabular}

Tabel 6. Hasil pengukuran pada lantai 2

\begin{tabular}{cccc}
\hline Waktu & Cell ID & Level Sinyal (dBm) & Waktu Layanan (s) \\
\hline $12: 30: 34$ & $230001-7$ & -102 & 4 \\
$12: 31: 03$ & $230021-6$ & -103 & 10 \\
$12: 32: 12$ & $230021-6$ & -99 & 8 \\
$12: 32: 59$ & $230021-6$ & -100 & 2 \\
$12: 33: 25$ & $230021-6$ & -99 & 16 \\
$12: 33: 57$ & $230021-6$ & -104 & 10 \\
$12: 34: 18$ & $230021-6$ & -99 & 6 \\
\hline $12: 35: 23$ & $230021-6$ & -97 & 4
\end{tabular}




\begin{tabular}{|c|c|c|c|}
\hline Waktu & Cell ID & Level Sinyal (dBm) & Waktu Layanan (s) \\
\hline Rata-rata Le & inyal $(\mathrm{dBm})$ & \multicolumn{2}{|c|}{-100} \\
\hline \multicolumn{4}{|c|}{ Tabel 7. Hasil pengukuran pada lantai 3} \\
\hline Waktu & Cell ID & Level Sinyal (dBm) & Waktu Layanan (s) \\
\hline $12: 41: 23$ & $404450-2$ & -109 & 8 \\
\hline $12: 43: 24$ & $404450-2$ & -105 & 4 \\
\hline $12: 43: 52$ & $404450-2$ & -104 & 12 \\
\hline $12: 44: 26$ & $404450-2$ & -100 & 2 \\
\hline $12: 44: 49$ & $404450-2$ & -99 & 10 \\
\hline $12: 45: 12$ & $404450-2$ & -96 & 4 \\
\hline $12: 46: 34$ & $404450-2$ & -97 & 4 \\
\hline $12: 47: 21$ & $404450-2$ & -99 & 8 \\
\hline \multicolumn{2}{|c|}{ Rata-rata Level Sinyal (dBm) } & \multicolumn{2}{|c|}{-99.7} \\
\hline
\end{tabular}

Tabel 8. Hasil pengukuran pada lantai 4

\begin{tabular}{|c|c|c|c|}
\hline Waktu & Cell ID & Level Sinyal (dBm) & Waktu Layanan (s) \\
\hline $12: 50: 06$ & $404450-2$ & -96 & 12 \\
\hline $12: 50: 31$ & $404450-2$ & -97 & 4 \\
\hline $12: 51: 01$ & $404450-2$ & -99 & 8 \\
\hline $12: 51: 49$ & $404450-2$ & -101 & 4 \\
\hline $12: 52: 03$ & $404450-2$ & -95 & 6 \\
\hline $12: 52: 41$ & $404450-2$ & -97 & 2 \\
\hline $12: 53: 26$ & $230021-6$ & -99 & 4 \\
\hline $12: 53: 57$ & $230021-6$ & -96 & 10 \\
\hline \multicolumn{2}{|c|}{ Rata-rata Level Sinyal (dBm) } & \multicolumn{2}{|c|}{-97.7} \\
\hline
\end{tabular}

Berdasarkan hasil pengukuran kualitas jaringan pada Tabel 5 - Tabel 8 terlihat bahwa rata-rata level sinyal provider 3 (Tri) yang diukur pada bangunan Rektorat Universitas Riau belum memenuhi standar, yaitu sebesar $-106 \mathrm{dBm}$ sampai $-97.7 \mathrm{dBm}$.

\subsection{Hasil Perhitungan}

Berdasarkan perhitungan link budget pada Tabel 5, diperoleh hasil MAPL uplink sebesar 167.415 $\mathrm{dBm}$ dan downlink sebesar $163.805 \mathrm{dBm}$. Dan berdasarkan perhitungan area cakupan, jumlah antena yang dibutuhkan adalah 6 buah pada setiap lantai .

\subsection{Perancangan Peletakan FAP dibagian Tengah Lorong}



Gambar 2. Peletakan FAP di Lorong Bagian Tengah Sejajar pada Setiap Lantai

Peletakan FAP dengan skenario bagian tengah lorong secara sejajar diletakkan dengan ketinggian 4 meter di plafon tiap lantai. Untuk masing-masing lantai diletakkan 6 FAP menurut perhitungan cakupan yang telah dilakukan sebelumnya. 

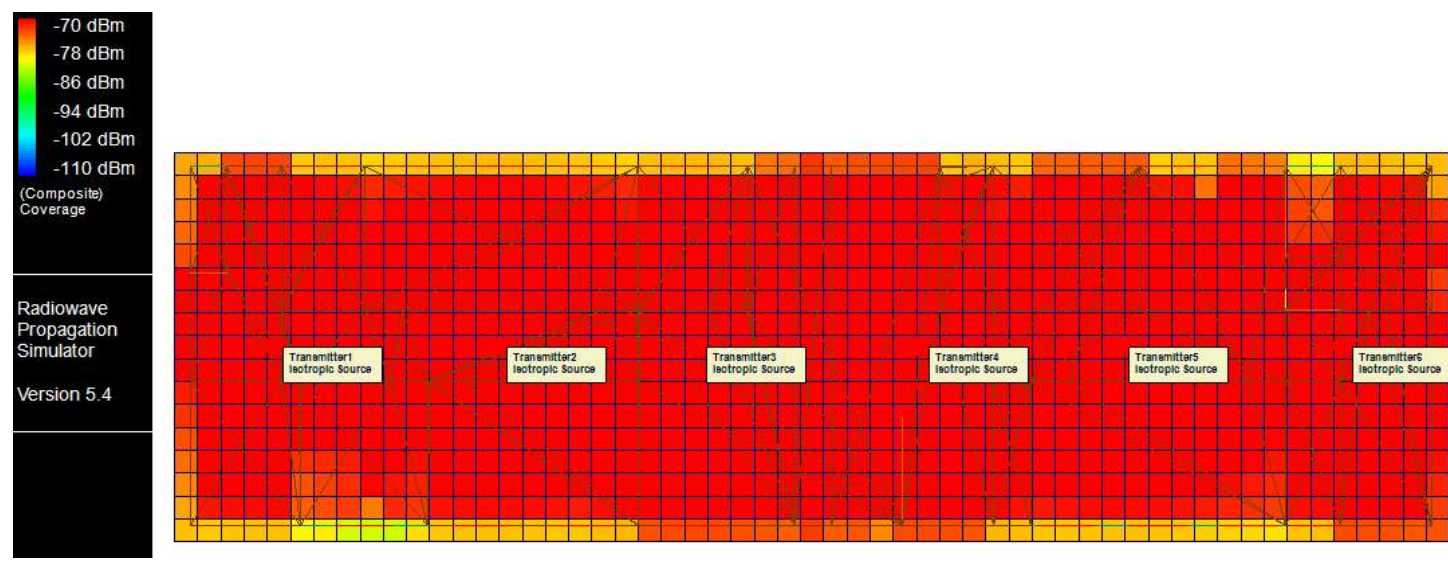

\section{Gambar 3. Simulasi Area Cakupan Lantai 1}

Dapat dilihat pada gambar 3 bahwa seluruh bagian dari ruangan sudah mendapatkan sinyal yang baik dengan dominan berwarna merah. Hasil simulasi ini menunjukkan hampir keseluruhan lantai 1 terlingkupi oleh sinyal FAP.

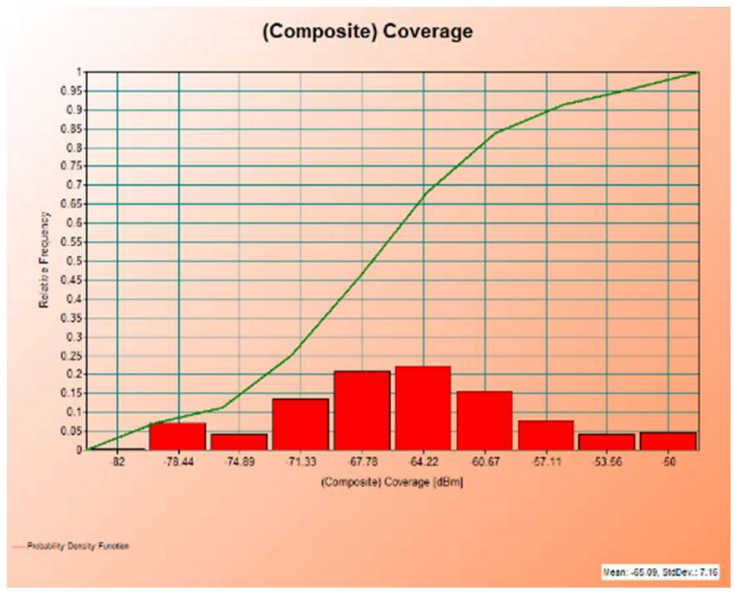

(a)

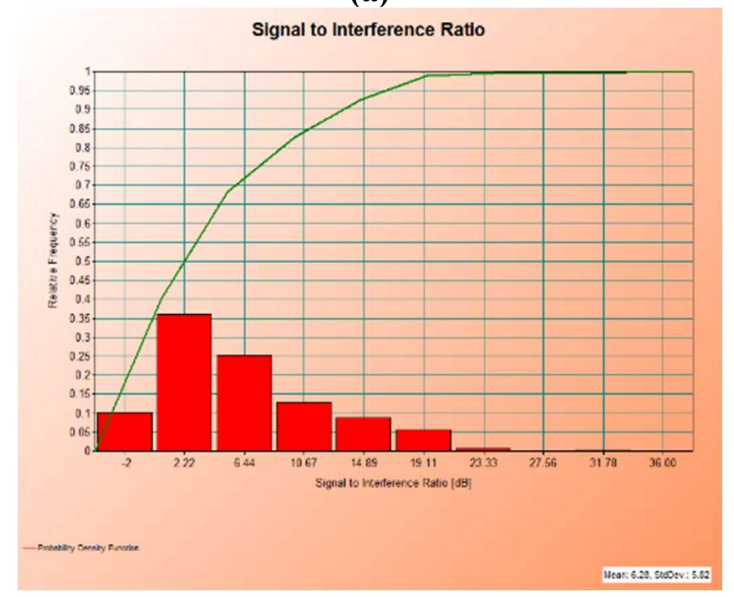

(b)

Gambar 4. (a) Histogram Area Cakupan Lantai 1 (b) Histogram SIR Lantai 1

Gambar 4 (a) menunjukkan hasil histogram cakupan pada lantai 1. Nilai relative frequency pada lantai 1 sebesar \pm 0.225 , ini berarti bahwa sebanyak $22.5 \%$ user mendapatkan level daya sebesar $-65,09 \mathrm{dBm}$. Kualitas sinyal hasil simulasi ini berada direntang Excellent atau Sangat Baik yaitu diatas $-90 \mathrm{dBm}$.

Gambar 4 (b) menunjukkan sebanyak 36\% user mendapatkan SIR (level signal to interference) sebesar $2.22 \mathrm{~dB}$ dan $25 \%$ user mendapatkan level signal to interference sebesar $6.44 \mathrm{~dB}$ yang berarti dalam keadaan normal. 

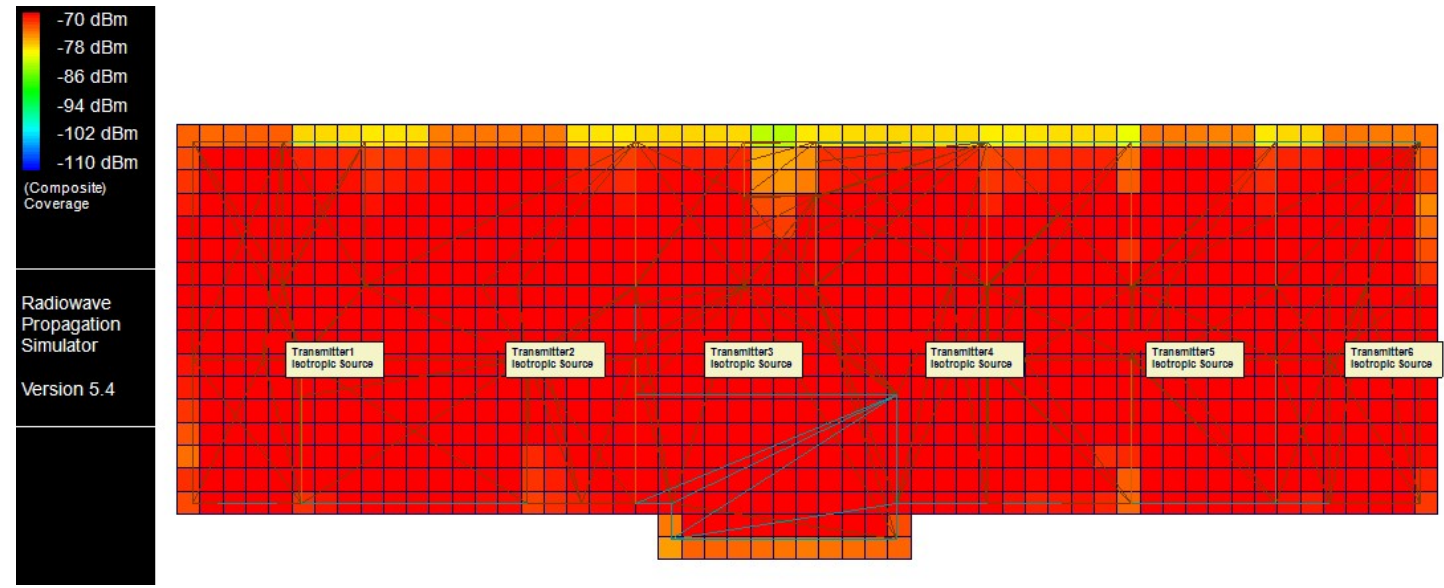

\section{Gambar 5. Simulasi Area Cakupan Lantai 2}

Dapat dilihat pada gambar 5 bahwa seluruh bagian dari ruangan sudah mendapatkan sinyal yang baik dengan dominan berwarna merah. Hasil simulasi ini menunjukkan hampir keseluruhan lantai 2 terlingkupi oleh sinyal FAP.

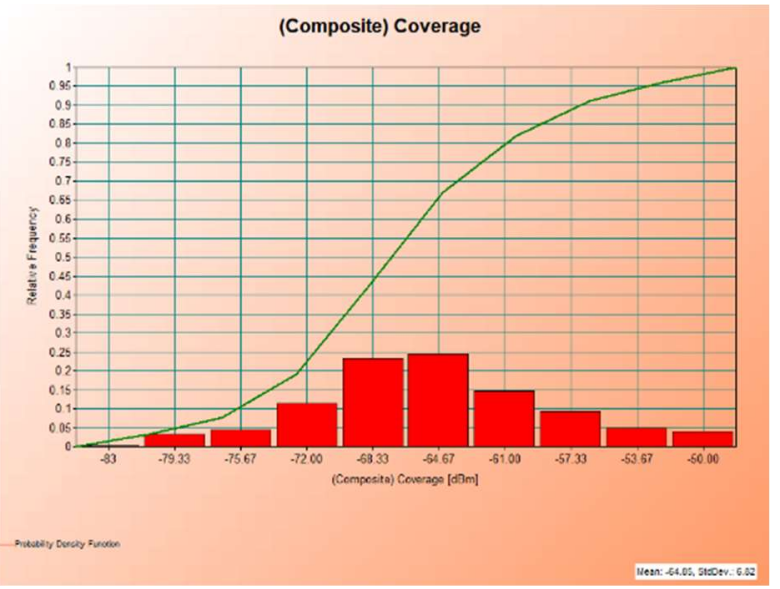

(a)

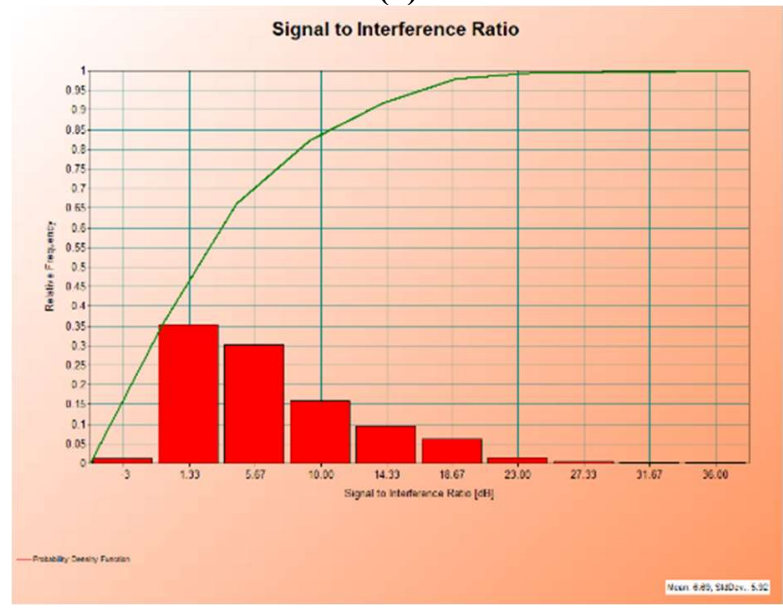

(b)

Gambar 6. (a) Histogram Area Cakupan Lantai 2 (b) Histogram SIR Lantai 2

Pada gambar 6 (a) menunjukkan hasil histogram area cakupan pada lantai 2. Nilai relative frequency lantai 2 sebesar \pm 0.25 , ini berarti bahwa sebanyak 25\% user mendapatkan level daya sebesar $-64.85 \mathrm{dBm}$. Kualitas sinyal hasil simulasi ini berada direntang Excellent atau Sangat Baik yaitu diatas $-90 \mathrm{dBm}$.

Gambar 6 (b) menunjukkan sebanyak 35\% user mendapatkan level SIR sebesar 1.33 dB dan 30\% user mendapatkan level SIR sebesar $5.67 \mathrm{~dB}$ yang berarti dalam keadaan normal. 

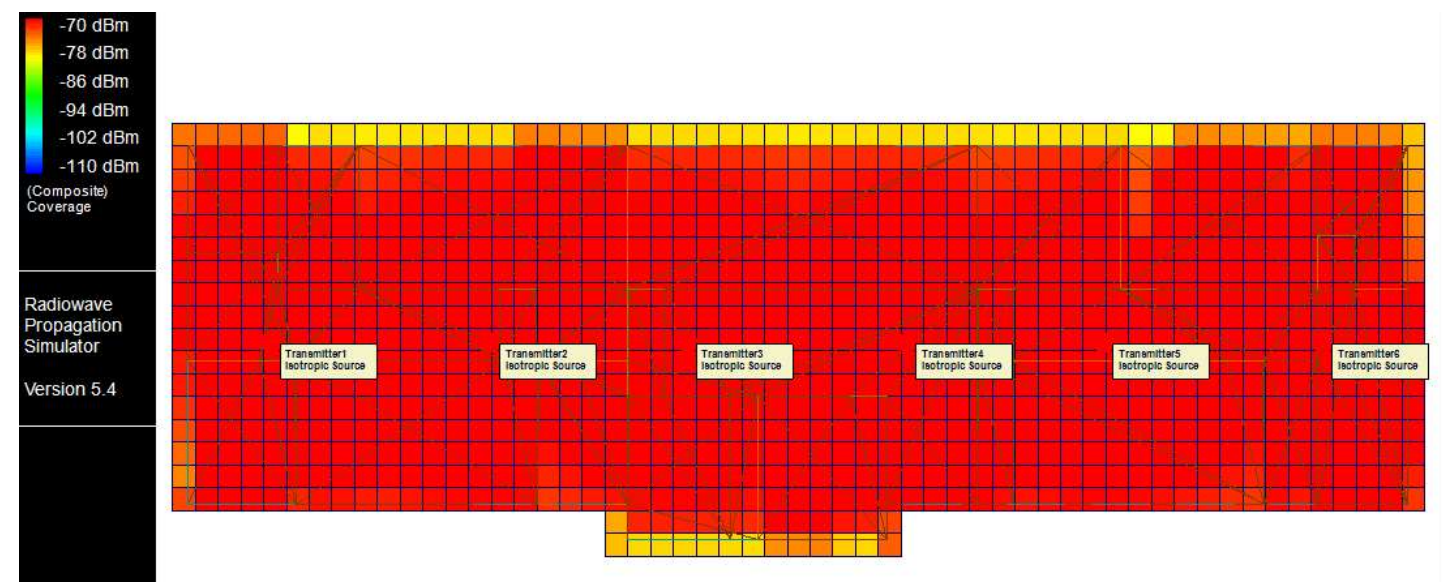

\section{Gambar 7. Simulasi Area Cakupan Lantai 3}

Dapat dilihat pada gambar 7 bahwa seluruh bagian dari ruangan sudah mendapatkan sinyal yang baik dengan dominan berwarna merah. Hasil simulasi ini menunjukkan hampir keseluruhan lantai 3 terlingkupi oleh sinyal FAP

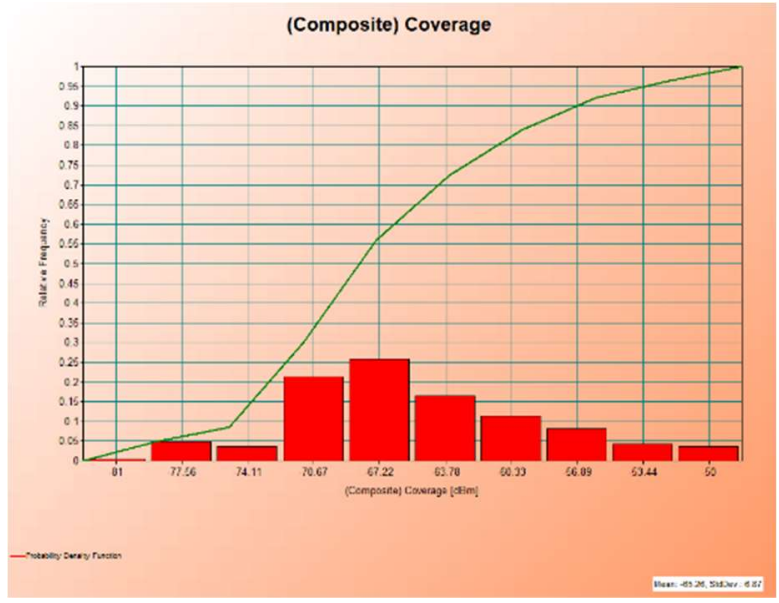

(a)

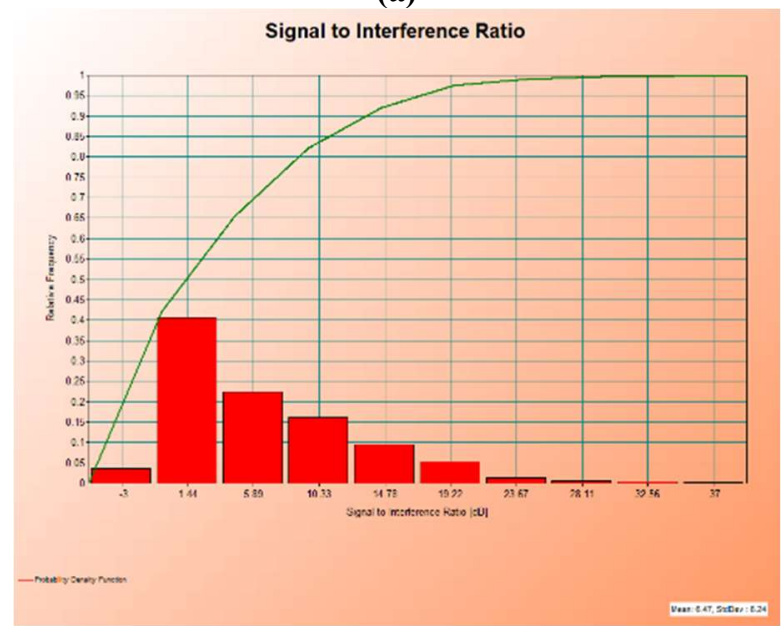

(b)

Gambar 8. (a) Histogram Area Cakupan Lantai 3 (b) Histogram SIR Lantai 2

Pada gambar 8 (a) menunjukkan hasil histogram area cakupan pada lantai 3. Nilai relative frequency lantai 3 sebesar \pm 0.26 , ini berarti sebanyak 26\% user mendapatkan level daya sebesar $-65.26 \mathrm{dBm}$. Kualitas sinyal hasil simulasi ini berada direntang Excellent atau Sangat Baik yaitu diatas $-90 \mathrm{dBm}$.

Gambar 8 (b) menunjukkan sebanyak 40\% user mendapatkan level SIR sebesar $1.44 \mathrm{~dB}$ dan 22.5\% user mendapatkan level SIR sebesar $5.89 \mathrm{~dB}$ yang berarti dalam keadaan normal. 

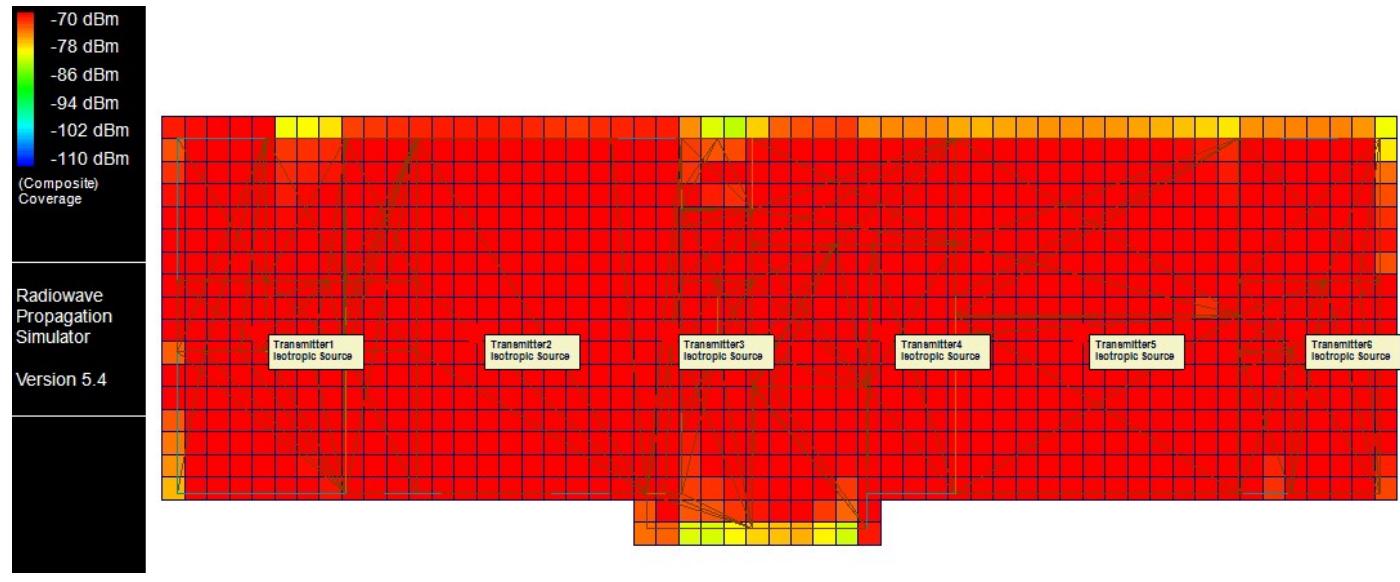

\section{Gambar 9. Simulasi Area Cakupan Lantai 4}

Dapat dilihat pada gambar 9 bahwa seluruh bagian dari ruangan sudah mendapatkan sinyal yang baik dengan dominan berwarna merah. Hasil simulasi ini menunjukkan hampir keseluruhan lantai 4 terlingkupi oleh sinyal FAP.

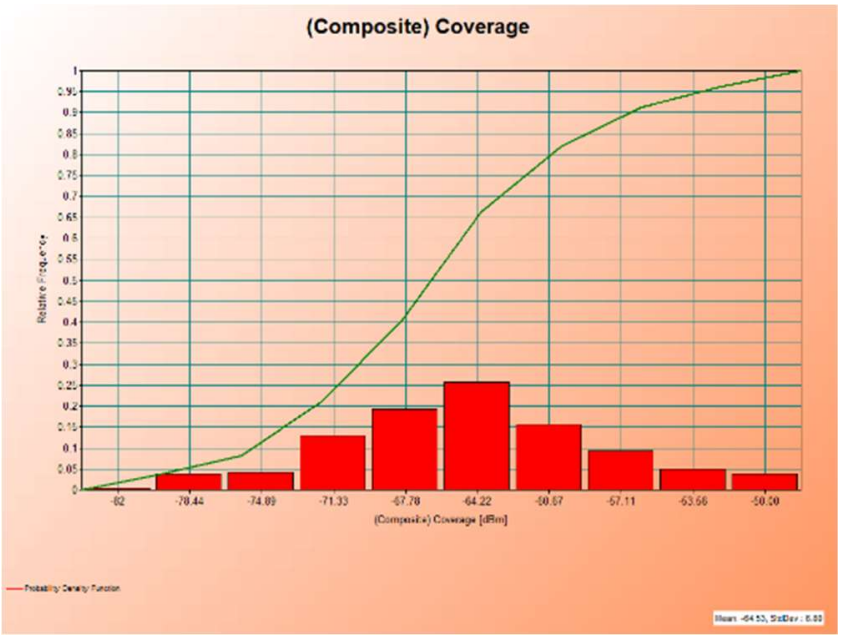

(a)

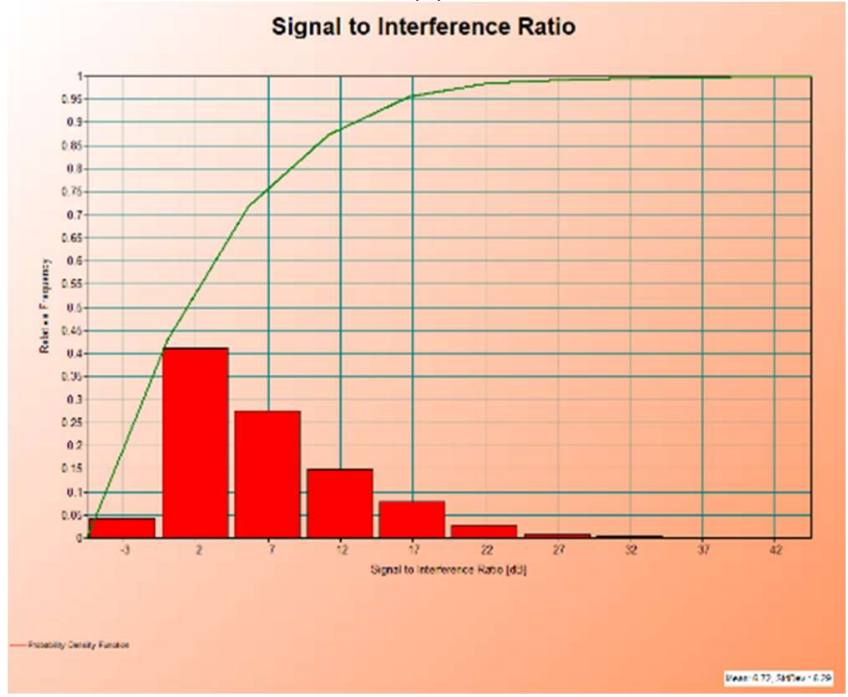

(b)

Gambar 10. (a) Histogram Area Cakupan Lantai 4 (b) Histogram SIR Lantai 4

Pada gambar 10 (a) menunjukkan hasil histogram area cakupan pada lantai 4. Nilai relative frequency lantai 3 yaitu sebesar \pm 0.25 , ini berarti sebanyak 26\% user mendapatkan level daya sebesar $-64.53 \mathrm{dBm}$. Kualitas sinyal hasil simulasi ini berada direntang Excellent atau Sangat Baik yaitu diatas -85 dBm. 
Gambar 10 (b) menunjukkan sebanyak 42\% user mendapatkan level SIR sebesar 2 dB dan 28\% user mendapatkan level SIR sebesar $7 \mathrm{~dB}$ yang berarti dalam keadaan normal.

Berdasarkan hasil simulasi skenario peletakan FAP dibagian tengah lorong secara sejajar di tiap lantai dapat dilihat keseluruhan level daya pada tiap lantai berada dalam kategori sangat bagus, karena sesuai dengan standar KPI yaitu $\geq-90 \mathrm{dBm}$. Untuk FAP ditempatkan pada plafon Gedung, sehingga dapat mencangkup semua user yang ada di setiap lantai pada gedung tersebut.

Dari simulasi yang dilakukan penempatan FAP yang dilakukan berdasarkan perhitungan area cakupan berhasil meningkatkan kualitas sinyal dimana pada keadaan awal kualitas sinyal pada gedung rata-rata memiliki level daya $\leq-100,91 \mathrm{dBm}$ sehingga kualitas performa sinyal yang didapatkan oleh user adalah buruk.

Nilai area cakupan level daya yang didapat sangat baik, yaitu dengan rata - rata sebesar -64.93 dBm. Dan untuk hasil histogram SIR juga menunjukkan nilai SIR rata-rata sebesar 6.72 dB. Semakin kecil nilai SIR menunjukkan perancangan jaringan indoor yang semakin bagus.

\section{KESIMPULAN}

Berdasarkan hasil perancangan FAP dan simulasi yang telah dilakukan pada Gedung Rektorat Universitas Riau, maka dapat disimpulkan bahwa:

a. Pada perancangan jaringan LTE pada provider 3(Tri) digunakan model propagasi COST 231 Multiwall. Dalam perhitungan yang telah dilakukan diperoleh skenario 6 buah FAP sejajar dibagian tengah lorong tiap lantai Rektorat Universitas Riau.

b. Daya pancar yang digunakan $23 \mathrm{dBm}$ sesuai dengan jenis FAP Isotropic Source sesuai dengan standar 3GPP. Diperoleh nilai MAPL sebesar 200,91 dB pada uplink dan pada downlink diperoleh sebesar 199,08 dB. Selisih MAPL yang didapat sebesar yang berarti masih layak untuk diterapkan pada perancangan.

c. Pada pengukuran awal kualitas sinyal provider 3(Tri) didapat nilai level daya rata-rata lebih rendah dari $-100,91 \mathrm{dBm}$ berada dalam kategori buruk. Perancangan dan simulasi skenario peletakan di tengah ruangan sejajar yang dilakukan diperoleh peningkatan kualitas sinyal sehingga rata-rata level daya menjadi $-64.93 \mathrm{dBm}$ yang pada standar KPI berada dalam kategori sangat bagus.

d. Hasil histogram SIR memiliki nilai SIR rata-rata sebesar $6.72 \mathrm{~dB}$ dimana peletakan FAP dibagian tengah lorong.

\section{DAFTAR PUSTAKA}

[1] O. Arafat, N. S. Nafi, and M. A. Gregory, "Priority based resource allocation for LTE-A femtocell networks," 2017 27th Int. Telecommun. Networks Appl. Conf. ITNAC 2017, vol. 2017-Janua, pp. 16, 2017, doi: 10.1109/ATNAC.2017.8215439.

[2] B. Utomo, I. Santoso, and A. A. Z, "Simulasi Link Budget Pada Sel Femto Teknologi Telekomunikasi Lte (Long Term Evolution)," Simulasi Link Budg. Pada Sel Femto Teknol. Telekomun. Lte (Long Term Evol., vol. 15, no. 1, pp. 13-18, 2013, doi: 10.12777/transmisi.15.1.13-18.

[3] F. I. Vera Desi Ramadianty, Dasril, "ANALISIS PENGUKURAN PERFORMANSI JARINGAN 4G LTE TELKOMSEL DALAM EVENT GAME MOBILE LEGENDS: BANG-BANG DI PONTIANAK," J. Tek. Elektro Univ. Tanjungpura.

[4] E. T. Tchao, J. D. Gadze, and J. O. Agyapong, "Performance evaluation of a deployed 4G LTE network," Int. J. Adv. Comput. Sci. Appl., vol. 9, no. 3, pp. 165-178, 2018, doi: 10.14569/IJACSA.2018.090325.

[5] S. I. Rezkika, S. Novalianda, and A. Ramadhan, "ANALISIS KEBUTUHAN PARAMETER JARINGAN LTE DENGAN METROPOLITAN CENTRE," pp. 31-36, 2019.

[6] F. Longoni, A. Lansisalmi, and A. Toskala, WCDMA for UMTS HSDPA Evolution and LTE. 2007.

[7] A. Hikmaturokhman, L. Berlianti, and W. Pamungkas, "Analisa Model Propagasi Cost 231 Multi Wall pada Perancangan Jaringan Indoor Femtocell HSDPA menggunakan Radiowave Propagation Simulator," Semin. Nas. Apl. Teknol. Inf., vol. 1, no. 1, pp. 1-9, 2015. 